\title{
FEMINISM AND DUALISM IN INTELLECTUAL PROPERTY
}

\author{
DAN L. BURK*
}

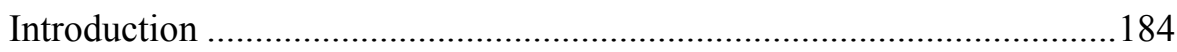

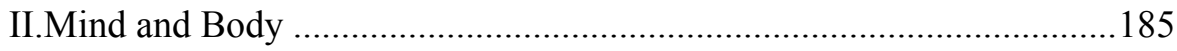

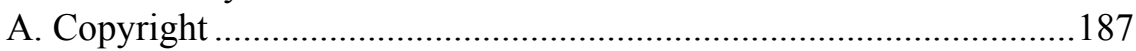

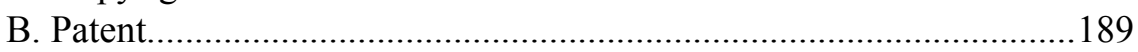

C. Feminist Perspectives................................................................. 191

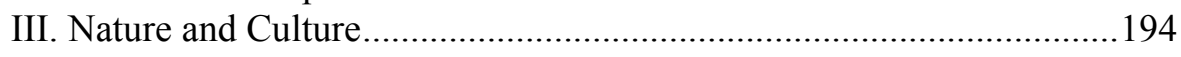

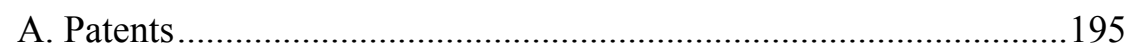

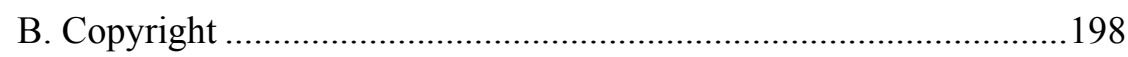

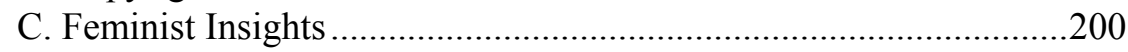

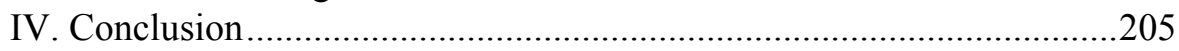

* Oppenheimer, Wolff \& Donnelly Professor of Law, University of Minnesota. Previous versions of this article were presented at the 14th Biennial Meeting of the Society for Philosophy and Technology in Delft, the Netherlands, on July $21^{\text {st }} 2005$ and at the American University Conference on IP and Gender: The Unmapped Connections, on March 24, 2006. I am particularly grateful to Peter Jaszi, Ann Shalleck, Vicky Phillips, Christine Haight Farley, Josh Sarnoff, Laura Heymann, Rebecca Tushnet, and other participants in the American University conference for their comments on the previous draft. 
Can the ardent feminist or critical race theorist say something, anything, about copyrights, patents, or trademarks? About bankruptcy, secured transactions, or reorganizations? About income, estates, or corporate tax? About contracts, property, or torts? ${ }^{l}$

[F]eminist inquiry is about understanding how things work, who is in the action, what might be possible, and how worldly actors might somehow be accountable to and love each other less violently. ${ }^{2}$

\section{INTRODUCTION}

In 1993, legal scholar Richard Epstein challenged the value and the utility of feminist scholarship in the academy, posing the question whether feminism had something, anything, to say about a variety of legal doctrines, including intellectual property. ${ }^{3}$ The question is somewhat surprising, especially in hindsight. Even at the time that he posed the question, feminist scholars had already begun addressing most of the topics Epstein recited in his litany of legal subject matter, ${ }^{4}$ and the literature on these topics continues to grow. Thus, the question might seem to have been answered even before it was posed or certainly in the years following; the substantial body of feminist literature exploring these subjects might be answer enough.

1. Richard A. Epstein, Legal Education and the Politics of Exclusion, 45 STAN. L. REV. 1607, 1624 (1993).

2. Donna Jeanne Haraway, The Companion Species Manifesto: Dogs, People, AND SIGNIFICANT OTHERNESS 7 (2003).

3. Epstein, supra note 1, at 1624.

4. See, e.g., Leslie Bender, An Overview of Feminist Torts Scholarship, 78 CORNELL L. Rev. 575 (1993); Leslie Bender, Feminist (Re) Torts: Thoughts on the Liability Crisis, Mass Torts, Power, and Responsibilities, 1990 Duke L.J. 848; Grace Blumberg, Sexism in the Code: A Comparative Study of Income Taxation of Working Wives and Mothers, 21 Buff. L. Rev. 49 (1971); Clare Dalton, An Essay in the Deconstruction of Contract Doctrine, 94 YALE L.J. 997 (1985); Mary Louise Fellows, Everett Fraser Professor of Law, Inaugural Address at the Univ. of Minn. Law Sch.: Wills and Trusts: "The Kingdom of the Fathers" (March 5, 1991), in 10 LAW \& INEQ. 137 (1991); Teresa A. Gabaldon, The Lemonade Stand: Feminist and Other Reflections on the Limited Liability of Corporate Shareholders, 45 VAND. L. REV. 1387 (1992); Karen Gross, Re-Vision of the Bankruptcy System: New Images of Individual Debtors, 88 Mich. L. REV. 1506 (1990) (reviewing Teresa A. Sullivan, Elizabeth Warren \& Jay Lawrence Westbrook, As We Forgive OuR DEBTORS: BANKRUPTCY AND CONSUMER CREDIT IN AMERICA (1989)); Gwen Thayer Handelman, Sisters in Law: Gender and the Interpretation of Tax Statutes, 3 UCLA WoMEN's L.J. 39 (1993); Marjorie E. Kornhauser, The Rhetoric of the Anti-Progressive Income Tax Movement: A Typical Male Reaction, 86 MicH. L. REV. 465 (1987); Kathleen A. Lahey \& Sarah W. Salter, Corporate Law in Legal Theory and Legal Scholarship: From Classicism to Feminism, 23 OSGOOdE HALl L.J. 543 (1985); Ramona L. Paetzold, Commentary: Feminism and Business Law: The Essential Interconnection, 31 AM. Bus. L.J. 699 (1994) (reviewing Mary Joe Frug, Women AND the LaW (1992), and PATricia SMith, FEMINIST JURISPRUDENCE (1993)). 
But the query was an obviously rhetorical question, evidently intended to imply that even if feminist theory is good for understanding anything in the law, it has little applicability outside a relatively small set of "women's issues," such as equal employment compensation, definitions and defenses in rape, and matters of family law. ${ }^{5}$ The substantive answer to this more serious, implied indictment was perhaps best articulated in the recent comment above by Donna Haraway, observing that feminist inquiry is fundamentally about determining who has power and how it is being used. ${ }^{6}$ Thus, feminist studies of law should be applicable not only to considerations of the impact of tax, contract, property, copyright, patent, trademark, tort, corporate, and business law on women, but also to exposing within these bodies of law the foundational cultural assumptions that affect both women and men.

Of the subjects Epstein recited in his jeremiad, feminist exploration of copyrights, patents, and trademarks has taken somewhat longer to emerge, but recently feminist commentators have begun to say something, indeed many things, about the law of intellectual property. ${ }^{7}$ In this essay I attempt to add somewhat to this growing body of scholarship, suggesting a new set of inquiries into the social roles played by intellectual property. In doing so, I point out certain conceptual and rhetorical structures in the law of both patents and copyrights that resemble those previously identified by feminist scholars in other contexts. These structures take the form of oppositional pairs that define much of the philosophical framework of intellectual property law. I first take up the dualism of mind and body that pervades both patent and copyright law. I then turn to the related dualism of nature and culture that is similarly found in both bodies of law. I argue that the feminist literature investigating such oppositional pairs can illuminate their function within the law of intellectual property, showing how intellectual property law contributes to determining and maintaining a pervasive set of power relationships in society.

\section{MIND AND BODY}

Intellectual property law constitutes one of the primary policy tools by which society influences the development and design of new technologies.

5. Cf. Epstein, supra note 1, at 1623-25.

6. See Haraway, supra note 2.

7. See, e.g., Ann Bartow, Fair Use and the Fairer Sex: A Gendered Story of Copyright Law, 14 AM. U. J. Gender Soc. PoL'Y \& L. 551 (2006); Dan L. Burk, Copyright and Feminism in Digital Media, 14 AM. U. J. Gender SoC. POL'y \& L. 519 (2006); Malla Pollack, Towards a Feminist Theory of the Public Domain, or Rejecting the Gendered Scope of United States Copyrightable and Patentable Subject Matter, 12 WM. \& MARY J. Women \& L. 603 (2006); Sean Robertson, Re-Imagining Economic Alterity: A Feminist Critique of the Juridical Expansion of Bioproperty in the Monsanto Decision at the Supreme Court of Canada, 2 U. OtTOWA L. \& TeCH. J. 227 (2005). 
Intellectual property law awards to creators exclusive rights in certain types of creative developments that meet highly particular statutory criteria. ${ }^{8}$ By rewarding certain types of technological development and penalizing others, intellectual property law is expected to promulgate an incentive structure that beneficially shapes the path of technology. ${ }^{9}$

However, the underlying philosophical basis for intellectual property rewards has gone largely unexamined, outside of fairly rote recitation of expected utilitarian benefits. On occasion, commentators will venture an alternative basis for the existence of the intellectual property system, ${ }^{10}$ but radical critiques outside the mainstream of the European philosophical tradition have been relatively rare. Focused critical examination of pervasive biases of the intellectual property system have been even rarer, although any number of curious features in the intellectual property system point to unstated, fundamental assumptions concerning the nature of knowledge and of the universe.

For example, it seems clear that implicit in the intellectual property system is a strong element of mind/body dualism, and this informs the system's incentives for technological development. Copyright law expresses this dualism as a highly rarified, almost mystical, view of the nature of creativity. The work that is created and owned by an author in copyright is idealized as an intangible form, which is then embodied or "fixed" in a tangible medium of expression." ${ }^{11}$ The parallel patent law doctrine of inventorship exhibits an even more striking pattern of dualism, as the patent right is defined by the "conception" of an invention in the mind of the inventor, rather than by the physical construction or "reduction to practice" of the invention.

These dualistic doctrines define those individuals or classes of individuals who will benefit from the reward system of intellectual property. In copyright law, it is ownership of the incorporeal work rather than ownership of the tangible embodiment that is privileged. In patent law, the actual building or "reduction to practice" of the invention is held largely irrelevant - it is the mental effort that counts, not the physical labor or material instantiation of the invention. Thus, a closer examination of the mind/body assumptions in intellectual property law may yield important insights into the biases or expectations latent in this reward system.

8. See, e.g., 17 U.S.C. $§ 106$ (2006) (cataloging the exclusive rights of copyright holders).

9. See William M. Landes \& Richard E. Posner, An Economic Analysis of Copyright Law, 18 J. LeGAL Stud. 325, 326 (1989).

10. See, e.g., Peter Drahos, A Philosophy of Intellectual Property (1996); Justin Hughes, The Philosophy of Intellectual Property, 77 GEO. L. REV. 287 (1988).

11. See 17 U.S.C. $\S 102$ (2006). 
The tools developed by feminist commentators are especially appropriate to such an exercise. Not only has feminist scholarship developed a rich body of work critiquing and exploring dualism and its effects, but it also has developed a methodology for extending such critiques to previously unexplored societal practices. A feminist approach encourages us to ask not so much where such intellectual property doctrines require us to draw the line between creativity that is rewarded and creativity that is not, as it requires us to ask why such criteria were selected in the first instance. The places where lines have been drawn may tell us something about the reason for the lines, which in turn tells us something about the implicit values held by society and by ourselves.

\section{A. Copyright}

The systems of intellectual property law developed by Western industrialized societies - and which, by virtue of aggressive treaty propagation, now extend to most jurisdictions in the world ${ }^{12}$ - purport to encourage creative activity by awarding creators an ownership interest in their work. ${ }^{13}$ This reward or incentive system of course requires some theory of creation, or definition of a creator, which is typically tied to an act of mind or will. In copyright law, for example, the act of creation is defined as one of intellectual effort, the mental creation of an idealized, intangible form. This flows from the definitional structure of the law, which sharply distinguishes between the protected work and its embodiment in a tangible copy. As defined in the copyright statute, the "work" created and owned by an author is conceptualized as an intangible form, a kind of mental construct generated by the creative genius of its originator. $^{14}$ This Platonic form of the author's expression is then embodied or "fixed" in a tangible medium of expression to create a "copy," which is then controlled by the author or copyright owner. ${ }^{15}$ Even when the embodiment exists as a single fixation, what in fine art might be called an original, for copyright purposes this remains a "copy"- that is, a copy of the intangible form.

Copyright attaches to the work at the moment of fixation. Ownership, then, depends upon the embodiment of the intangible work, but it is the

12. See, e.g., Agreement on Trade-Related Aspects of Intellectual Property art. 9(1), Apr. 15, 1994, 33 I.L.M. 81 [hereinafter TRIPS]. Consequently, while I will cite primarily to provisions of United States intellectual property law in this paper, similar or identical provisions will be found in the national law of countries adhering to international agreements, such as TRIPS.

13. See Sony Corp. of Am. v. Universal City Studios, Inc., 464 U.S. 417 (1984); Diamond v. Chakrabarty, 447 U.S. 303 (1980); Mazer v. Stein, 347 U.S. 201, 219 (1954).

14. 17 U.S.C. $\S \S 101,102$ (2006).

15. Cf. 17 U.S.C. $\S 101$. 
intangible work rather than the physical embodiment that defines the author's rights. Under this system, ownership of the incorporeal work and ownership of the tangible embodiment may be bifurcated. Thus, a consumer may purchase a book or a music $\mathrm{CD}$ and may typically dispose of the physical object however she pleases - by reselling it, giving it away to a friend, tossing it into the trash bin, or setting it on fire. ${ }^{16}$ What the owner of the physical object typically may not do is to dispose of it in one of a small number of restricted manners that implicate the embodied work - using the object as a template for making additional copies, for example. ${ }^{17}$ Such activity is prohibited because it effectively produces additional embodiments of the work. The right of embodiment-in statutory terms, the right of reproduction-is reserved to the author.

In order to qualify for copyright protection, the intangible work must constitute the original expression of the author. ${ }^{18}$ "Original" in this sense connotes that the expression must originate with the author; it must not be derived from somewhere else. ${ }^{19}$ The generation of original expression is what makes one an author for copyright purposes. The copyright statute thus assumes that creative expression arises from authors ex nihilo, solely from the author's own creative genius. This doctrine reflects copyright's embrace of a romanticized version of authorship, arising out of eighteenth and nineteenth century notions of artistry, which assume that protectable works are the result of the creative efforts of a single artistic genius. ${ }^{20}$ This view tends also to assume that collaborative work is a rare anomaly and ignores or subordinates the predicate contributions of non-authors from whom an author may draw. Thus, to become a joint author, an individual must contribute to the work's original expression that would be independently copyrightable. ${ }^{21}$ Additions to the work made without permission will generally run afoul of the author's exclusive right to create and authorize derivative works. ${ }^{22}$ Unauthorized derivative works are denied any copyright protection at all, effectively placing the unauthorized contribution under the control of the initial author. ${ }^{23}$

16. See 17 U.S.C. $§ 109$ (a).

17. See 17 U.S.C. $\S 106$.

18. See 17 U.S.C. $\S 102$.

19. See Feist Publ'ns, Inc. v. Rural Tel. Serv. Co., 499 U.S. 340, 345-46 (1991).

20. See Peter Jaszi, Toward a Theory of Copyright: The Metamorphoses of "Authorship," 1991 DUKE L.J. 455, 455-68 (discussing the Romantic hierarchy of arts and the superior value placed on the works of imagination); Martha Woodmansee, On the Author Effect: Recovering Collectivity, 10 CARDOZO ARTS \& ENT. L.J. 279, 291 (1992) (noting that Romantic era authors considered the writing process to be solitary, rather than collaborative).

21. See 17 U.S.C. $\S 101$.

22. See 17 U.S.C. $\S 106$.

23. See 17 U.S.C. $\S 103(a)$. 


\section{B. Patent}

Copyright law is not alone in its bifurcation of mind over matter or in the elevation of the mental over the physical. Much as copyright focuses on an idealized concept of the copyrighted work to define the creative act, so patent law focuses on an idealized version of invention. The parallel patent law doctrine to authorship, inventorship, shows an even more striking pattern of dualism, which is perhaps most apparent in the patent law of the United States. ${ }^{24}$ Unlike the rest of the world, the United States is a "first to invent" jurisdiction in which patents are awarded to the first inventor in time. $^{25}$ Elsewhere, the patent for an invention claimed by two inventors will be awarded to the first inventor to file an application with the patent office, but in the United States, priority in invention, rather than priority in filing, takes precedence. ${ }^{26}$

As a result, in the United States, defining the act of invention is critical to determining when it occurred. Priority of invention is decided primarily on the basis of conception - surely an evocative and loaded term - which is classically defined as the formation in the mind of the inventor of the complete and operative image of the invention as defined in the claims of the written patent. ${ }^{27}$ As an evidentiary matter, full conception of the invention is considered to be shown when the operative invention has been "reduced to practice"; that is, when it is actually built or implemented. ${ }^{28}$ It may also be constructively reduced to practice when effectively described in a patent application. ${ }^{29}$ But the mental formation of the invention may have occurred much earlier, and if documentary or testimonial evidence of a complete conception can be shown, priority will be dated back to the time of the mental development.

Thus, the mental act of conception is the dominant factor in determining inventorship. Numerous cases state that once the concept of the invention is complete, one of ordinary skill should then be able to build it, or in patent terms, to reduce it to practice. ${ }^{30}$ Far from being one of ordinary skill, the inventor is by definition one of extraordinary skill, so that once

\footnotetext{
24. See 35 U.S.C. $\S \S 101,102$ (2006).

25. See 35 U.S.C. $\S 102(\mathrm{~g})$.

26. Compare 35 U.S.C. $\S 102(\mathrm{~g})$ (stating that patent will be granted to the inventor who is able to show that he was first to conceive of the invention), with European Patent Convention 2000 art. 60(2), June 28, 2001, European Patents, Oct. 5. Convention on the Grant of 1973, 13 I.L.M. 268 (stating that when two separate persons file for a patent on the same invention, the patent will go to the inventor who filed his application first in time).

27. See Townsend v. Smith, 36 F.2d 292, 296 (C.C.P.A. 1929).

28. See id.

29. See Feldman v. Aunstrup, 517 F.2d 1351, 1355 (C.C.P.A. 1975).

30. See, e.g., Burroughs Wellcome Co. v. Barr Labs., Inc., 40 F.3d 1223, 1228 (Fed. Cir. 1994).
} 
the mental work has been completed, all that remains to be done has been characterized as the "work of the mere artisan"- not the work of an inventor. ${ }^{31}$ Indeed, physical reduction to practice is largely irrelevant, as patent law allows for descriptive, constructive reductions to practice. ${ }^{32}$ There is no need to actually build the working invention. Instead, if the inventor's conception is complete enough to convey to one of ordinary skill how to make and use the invention, the inventor may describe the invention in the patent document and file a "paper patent" without actual construction or reduction to practice. ${ }^{33}$ In either case, the inventor need not even know or expect that the invention will work - that is, again, a problem for the mere artisan. ${ }^{34}$ The act of invention is one of forming an idea in final form, not of knowing whether it will work when built.

Consequently, additions, suggestions, or contributions that are appended to the invention after the idea is formulated are not recognized as a contribution toward inventorship, even if those additions are necessary to build, test, or refine the invention. ${ }^{35}$ Any failure of an invention that has been actually or constructively reduced to practice is considered a failure of the conception, rather than a failure of the material instantiation. If the invention fails it was because the conception was incomplete, so the invention as constructed failed to work properly. A more complete conception, rather than recognition of the vicissitudes of materiality, is considered the answer to the failure.

This focus on the mental part of inventive activity, like copyright's focus on the intangible work, has its roots in nineteenth century notions of the solitary creative genius. Patent law implicitly assumes a lone, extraordinary individual to be the source of new inventions. ${ }^{36}$ This "heroic inventor" of patent law is the sibling if not the identical twin of copyright's romantic author. Joint inventorship is acknowledged only grudgingly within the patent system; to qualify as a joint inventor, an individual must assist in solving the inventive problem by making an original contribution to the conception of the invention. ${ }^{37}$ Multiple contributions to the invention resulting in multiple claimants to ownership, as is the common practice in

31. See Townsend, 36 F.2d at 295.

32. See Feldman, 517 F.2d at 1355.

33. See Burroughs, 40 F.3d at 1231.

34. See Applegate v. Scherer, 332 F.3d 571, 573 (C.C.P.A. 1964).

35. See Burroughs, 40 F.3d at 1229-30. (2002)

36. See Mark D. Janis, Patent Abolitionism, 17 Berkeley TeCh. L.J. 899, 910-16

37. Cf. 35 U.S.C. $§ 116$ (2006) (providing for applications of joint inventorship); Kimberly-Clark Corp. v. Procter \& Gamble Distrib. Co., 973 F.2d 911, 917 (Fed. Cir. 1992) (discussing conceptual contribution necessary to joint inventorship); Monsanto Co. v. Kamp, 269 F. Supp. 818, 824 (D.D.C. 1967). 
modern corporate research settings, has created ongoing problems within patent law and has only been very slowly accommodated within the statute. $^{38}$

\section{Feminist Perspectives}

The repeated occurrence of these dualistic themes in intellectual property law suggests a broad variety of implications incident to the structure of such dualism. The exploration and critique of mind/body dualism has a long and voluminous history in Western philosophy, and many of the insights generated by this centuries-old debate might be profitably applied to an analysis of intellectual property law. A full discussion of all, or even a few, of these insights lies far beyond the scope of this essay. Instead, I shall focus on one particular, relatively recent theme in the mind/body discussion arising out of the feminist critique of dualistic paradigms.

Feminists have explored the tendency of Western philosophy and practice to divide subjects into oppositional categories including not only masculine/feminine, but also mind/body, nature/culture, public/private, active/passive, reason/emotion, subject/object. ${ }^{39}$ In each of these dichotomous pairings, the former is typically, if sometimes implicitly, regarded as superior and masculinized, and the latter considered inferior and feminized. ${ }^{40}$ Feminist commentators have suggested that such designations allow the feminized categories to be branded as "other," as conditionally flawed or undesirable. ${ }^{41}$ The elevation of "mind" and "spirit" over "body" and "matter" have been particularly identified with social predominance of reason and objectivity, which are in turn tied to a masculinized framing of other subordinated categories of gender, race, and class. $^{42}$ Thus, in his Politics, Aristotle justifies the practice of slavery by arguing that: just as the mind or spirit is superior and should rule the body; just as men as a gender are by nature rational and therefore superior, and should properly rule over women; just as humans are by nature rational and therefore superior to animals, and should rule over them, by the same logic, some classes or races who are more rational should properly rule over other (2004)

38. See Dan L. Burk, Intellectual Property and the Firm, 71 U. CHI. L. REV. 3, 15-16

39. See generally Raia Prokhovnik, Rational Woman: A Feminist Critique of DUALISM (1999).

40. See Val Plumwood, Feminism and the Mastery of Nature 32, 42-43, 47 (Teresa Brennan ed., 1993). See generally Genevieve Lloyd, The MAN OF ReASON: "MALE" AND "FemAle" IN Western Philosophy (1984) (arguing that, traditionally, men were believed to be rational and superior to their irrational female counterparts).

41. See SAndra HARding, The Science Question In FEminism 172 (1986) (explaining that Euro-American imperialists considered non-Europeans as "others" and inferior, and that the notion of "otherness" extended to feminine categories also considered to be inferior).

42. See Plumwood, supra note 40 , at 43 . 
races, who should properly be slaves. ${ }^{43}$

Dualism thus sets the stage for the supposedly inferior, feminized category to be given a status that allows domination and exploitation by members of the privileged category; it is a social and rhetorical strategy that "naturalizes domination." 44 Although the modern reader is likely to find nearly every step of Aristotle's slavery syllogism to be repugnant, feminist commentators have argued that its premises of superiority are deeply embedded in the fabric of Western culture. ${ }^{45}$ While those premises may no longer explicitly justify slavery, they may continue to animate attitudes or cultural legacies of inequality. Social practices or disciplines that valorize rationality may be particularly suspect, given the longstanding conceptual linkages between reason and canons of subordination. For example, Aristotle's complex of oppressive associations may be foundational to Western notions of science, technology, and progress. ${ }^{46}$

This critique of dualism closely relates to the important theme of "invisible work" that has also been discussed by a range of feminist commentators. ${ }^{47}$ Owing much of their analysis to Marxist critiques, this literature observes that the bifurcation of social roles into masculine and feminine, and into public and private, obscures and subordinates certain social roles, relegating certain types of work to the private sphere, and so to the realm of "feminine" labor. ${ }^{48}$ Much of this work is domestic and menial and goes largely unrecognized, even though it is essential to the day-to-day operation of families, firms, and other social institutions. Such work, often performed by women, tends to be low-pay, or in the case of household labor, entirely unpaid. Thus, a great deal of labor that supplies the basic needs of society goes unseen and unrewarded, leading feminist commentators to remark upon the systematic disparity in categories of occupation. This in turn has led them to identify and analyze the gendered nature of recognition for labor. ${ }^{49}$

The same patterns recognized in domestic and menial labor appear to hold true in our system for rewarding innovation and creativity. As described above, copyright and patent law elevate mental effort over physical effort, conceptual production over material production, thus tying

43. Aristotle, Politics: Book I And II 75 (Trevor J. Saunders trans., 1995).

44. Rosemary Radford Ruether, New Woman New Earth: Sexist Ideologies and HumAn Liberation 189 (Myra E. Barrer ed., 1975).

45. See id.

46. See Susan Bordo, The Flight to Objectivity 104 (Robert C. Neville ed., 1987).

47. See generally Ruth Schwartz Cowan, More Work for Mother: The Ironies of Household Technology From the Open Hearth to the Microwave (1983).

48. See Maxine L. Margolis, Mothers and Such: Views of American Women and WHY THEY CHANGED (1984).

49. See id. at 262-63. 
ownership and economic rewards to participation in an idealized, romantic vision of creative production. Participants in the messier, corporeal, material development or execution portions of the creative process are excluded, invisible, unrecognized. This version of creative effort effectively vests ownership in a single or limited number of participants, attributing the entirety of creative production to a particular, discrete act of creative vision.

But the production of creative works does not occur in splendid isolation-certainly such is not the case in modern production of copyrighted works, if indeed it ever was. Creative works are instead the result of an extended system of production. This is true not only with regard to the intangible work itself, which postmodern critiques have shown typically arises out of the creative input of many contributors and within a social matrix of previously generated cultural objects, ${ }^{50}$ but also with regard to the actual physical production of copies, which requires extended support and collaboration from a network of contributors. Such extended collaboration is perhaps most starkly obvious to us as the extensive credits of a motion picture roll by, typically after the end of the show when everyone has left the theater, briefly acknowledging the involvement of the gaffer, the best boy, the key grip, the prop and wardrobe workers, and typically the hundreds of other motion picture production participants.

The contributions of such individuals are recognized for a few seconds at the end of the film, but not in the reward system of copyright law. A considerable body of case law emphasizes that the efforts of camera operators or creative consultants who arrange the action for filming do not rise to the level of authorship recognized under the copyright system. ${ }^{51}$ Neither is this situation unique to the motion picture industry. The pervasive involvement of unrecognized contributors is likely the rule in copyright rather than the exception; industries dominated by copyrighted works are rife with legions of studio musicians, editors, sound engineers, stage hands, lighting technicians, and "ghost" writers without whom there would be no creative works, but who remain quite invisible to the copyright definitions of "originality" and "authorship." "52

Similarly, new inventions are not produced in heroic isolation; postmodern critics are surely correct that the inventor is just as dependent on the milieu of creation and the incremental contributions of previous

50. See generally Pollack, supra note 7 (contending that limiting copyright protection to an individual is "an inherently male approach to the world").

51. See, e.g., Aalmuhammed v. Lee, 202 F.3d 1227, 1234 (9th Cir. 2000); Lindsay v. R.M.S. Titanic, No. 97 Civ. 9248 (HB), 1999 WL 816163, at *6 (S.D.N.Y. 1999).

52. See Thomson v. Larson, 147 F.3d 195, 204 (2d Cir. 1998). 
researchers as is the not-so-romantic author. ${ }^{53}$ But setting aside for the moment those general foundations of shared knowledge upon which innovation is built, much of inventive activity, and perhaps the majority of inventive research, occurs in collaborative groups. Modern research programs depend upon a host of laboratory technicians, research assistants, process engineers, machinists, drafters, interns, graduate students, and materials specialists who may well have direct, hands-on contact with the building and testing of the invention - not to mention the secretaries, janitors, bottle washers, supply clerks, librarians, and even patent attorneys who indirectly support the development of the invention. These "mere artisans" are not the "heroes" of the inventive process, and their contributions to the embodiment of the inventor's ideas will tend to go unrecognized. They do not contribute to the idealized "conception" of the invention, and so their involvement is, so far as patent law is concerned, quite invisible.

As in other areas where feminist commentators have identified attitudes and practices designating some work as socially invisible, the legal bifurcation of creativity into oppositional mental and physical efforts shunts reputation and reward to a relatively small but privileged portion of the creative process. $^{54}$ By excluding from consideration creative contributions related to the physical instantiation of creative works, intellectual property law excludes particular classes of contributors from recognition and ownership. Those excluded constitute not only a class of unrecognized contributors to the creative process for purposes of copyright and patent law, but frequently are those in positions of lower status and pay, and in many cases may be predominantly female. Thus, intellectual property dualism appears to reinforce socially established structures of hierarchy within creative endeavor and to allow certain valorized contributors to dominate the creative process so as to reap the rewards bestowed under the copyright and patent statutes.

\section{NATURE AND CULTURE}

The oppositional categories of mind and body are not the only dualism embedded in intellectual property law that has been discussed in feminist scholarship. Among the other troublesome dualisms identified and critiqued by feminist scholars is that which opposes the natural world to the results of human activity, a divide between nature and culture. Appeals to nature have an unsavory history in justifying oppressive dualisms - recall the justification of slavery by Aristotle based upon the irrational nature of

53. See Burk, supra note 38, at 16.

54. See Bartow, supra note 7, at 552. 
women and other inferior peoples and the "natural" state of mastery occupied by rational, presumably Greek, men. ${ }^{55}$ But Aristotle's comparison also celebrated human rationality as superior to that of animals, distancing humans from "nature" in a different sense and justifying domination of humans over their environment.

Feminists were by no means the first to note the charged societal character of such concepts. Speaking of the terms "natural" and "nature," John Stuart Mill observed that:

[I]t is unfortunate that a set of terms which play so great a part in moral and metaphysical speculation, should have acquired many meanings different from the primary one, yet sufficiently allied to it to admit of confusion. The words have thus become entangled in so many foreign associations, mostly of a very powerful and tenacious character, that they have come to excite, and to be the symbols of, feelings which their original meaning will by no means justify; and which have made them one of the most copious sources of false taste, false philosophy, false morality, and even bad law. ${ }^{56}$

Intellectual property law may well fit within the categories of "bad law" that Mill predicted. Like the opposition of mind and body, the opposition of nature and culture is a fundamental tenet of the law concerning copyrights and patents, although this opposition has gone largely unnoticed. The tools of feminist critique allow us to recognize such tenets, examine more effectively the assumptions behind their presence in intellectual property, and to assess their effects.

\section{A. Patents}

A dualistic concept of nature has long been integral to defining the subject matter of patent law. The patent statute lists new and useful processes, machines, articles of manufacture, and compositions of matter as patentable subject matter. The Supreme Court has held this litany of categories to be illustrative, rather than exhaustive. According to the legislative history of the patent statute, as famously confirmed by the Supreme Court in Diamond v. Chakrabarty, patentable subject matter includes "anything under the sun that is made by man," meaning anything made by humankind, of course..$^{57}$

The corollary is the inverse proposition that patentable subject matter does not include those things not made by man (meaning those things not

55. See ARISTOTLE, supra note 43, at 6-7 (analogizing the superiority of the mind over the soul to that of man over woman because this is "both natural and beneficial").

56. John Stuart Mill, Three EsSAys on Religion 3 (1884).

57. 447 U.S. 303, 309 (1980) (citing S. Rep. No. 1979, at 5 (1952); H.R. Rep. No. 1923 , pt. 1, $6(1952))$. 
made by humans, of course). Such unpatentable subject matter is labeled as "products of nature," which courts have defined as including natural substances; that is, materials drawn from nature unaltered, or at least insufficiently altered, by human intervention. ${ }^{58}$ The degree of human intervention or change required to move materials into the category of patentable subject matter has long been unclear and problematic. Thus, in Funk Bros. v. Kalo Inoculent, the Supreme Court held unpatentable a mixture of bacterial strains that were useful in nourishing the growth of certain agricultural plant root nodules. ${ }^{59}$ The bacterial mixture itself did not occur naturally, but the Court reasoned that there had been no patentable change in the properties of the bacterial species; they performed the same metabolic functions in the mixture that they performed in the wild. ${ }^{60}$

At the same time, courts now routinely allow the patenting of biological materials, such as hormones, enzymes, and DNA sequences. The patenting of such biomolecules has become routine, although in some sense these substances are drawn from and exist in nature. Because some biological molecules described in patent claims might be extracted from nearly any human body, these claims have generated controversy around the world. U.S. courts have held, however, that isolating and purifying such substances changes them sufficiently from their natural state to place them within patentable subject matter. ${ }^{61}$ A protein or DNA sequence in isolation under this standard is not the same protein or DNA sequence found in the wild, mixed and networked with all manner of other biological molecules. ${ }^{62}$ This redefinition of "natural" has allowed the issue of patents to be raised on a range of materials that many observers might intuitively feel are "discoveries" rather than "inventions.",63

A related set of prohibitions from patentable subject matter excludes scientific "laws" of nature and principles of mathematics. The premise behind these exclusions is also that such categories constitute "discoveries" by humans, rather than "inventions" created by humans. ${ }^{64}$ But this premise is highly problematic. Mathematics presents the clearest difficulty for such classification. There exists a fairly strong argument that mathematics is a human construction, not an inherent property of the universe itself. ${ }^{65}$

58. 35 U.S.C. § 101 (2006); Diamond v. Chakrabarty, 447 U.S. 303, 313 (1980).

59. See Funk Bros. Seed Co. v. Kalo Inoculent Co., 333 U.S. 127, 130 (1948).

60. See id. at 131 .

61. See, e.g., Amgen, Inc. v. Chugai Pharm. Co., 927 F.2d 1200, 1206 (Fed. Cir. 1991).

62. See Parke-Davis \& Co. v. H.K. Mulford Co., 189 F. 95, 103 (S.D.N.Y. 1911) (holding that adrenaline purified from biological materials was patenably novel because it "became for every practical purpose a new thing commercially and therapeutically").

63. See id. at 113-14.

64. See Gottschalk v. Benson, 409 U.S. 63, 71-72 (1972); Funk Bros., 333 U.S. at 130.

65. See Phillip J. Davis \& Reuben Hersh, The Mathematical Experience 321 
Mathematics may be congruent with the universe to the extent that it is used to describe the universe. If considered a language, it seems even less clear that mathematics should be considered a function of "nature" rather than a matter of human construction. Even if mathematics as a language may describe reality or express statements about reality this does not seem to make the language necessarily a product of nature. English or Swahili can also describe reality, or express statements about reality, but it would be an exceedingly odd ontological maneuver to conclude on that basis that those languages have independent existence apart from human usage. ${ }^{66}$

In each of these cases, the separation of natural from artificial partakes of the problems identified above by Mill. The exercise of defining the natural is on some level at least tautological, if not altogether untenable. As Bertrand Russell observed, "[m]an is a part of nature, not something contrasted with nature. His thoughts and his bodily movements follow the same laws that describe the motions of stars and atoms." are a part of nature as are artifacts constructed by humans-beavers build dams, bees build beehives, humans build cathedrals, semiconductor chips, alloys, and nectarines. ${ }^{68}$ Even if one construes nature as something different from human construction, such constructions must at some level be based upon laws and materials drawn from the physical, natural world. The Supreme Court has recognized this problem, noting that a rule which excludes embodiments of "laws of nature" from patentability could, if taken to its logical conclusion, exclude all inventions from patent law. ${ }^{69}$ Thus, on one interpretation the products of nature doctrine could include everything within patentable subject matter, while on the other interpretation it could exclude everything from patentable subject matter. Given that other patent doctrines may have the capability of identifying those human contributions that promote progress, ${ }^{70}$ one wonders why such

(1980).

66. This seems more a statement of faith, as in the case of some forms of Judaism holding that the Torah exists independently of God or humankind, such that the text's existence preceded its revelation to humans by God. See, e.g., GerShom SCHOLEM, KABBALAH 132 (1974) ("In effect, [the primordial Torah] was a kabbalistic version of the Platonic world of ideas."); $c f$. JOHN MARSH, The GOSPEL OF SAINT JOHN 96-97 (D.B. Ninham ed., 1983) (noting that the author of the Johannine gospel identified the premortal Jesus with the tradition of the primordial Torah in John 1:1, "[i]n the beginning was the Word").

67. Bertrand Russell, What I Believe, in Why I Am Not a Christian AND Other EsSAYS ON RELIGION AND RELATED SubJeCts 48, 48 (1967) (Paul Edwards ed., 1957).

68. See J. Baird Callicott, The Wilderness Idea Revisited: The Sustainable Development Alternative, 13 ENVTL. Prof. 235, 240-41 (1991).

69. See Diamond v. Diehr, 450 U.S. 175, 189 n.12 (1981).

70. See Dan L. Burk \& Mark A. Lemley, Inherency, 47 WM. \& MARY L. REV. 371, 407 (2005) (arguing that the patent doctrine of "inherency" appears adequate to accomplish the same goal). 
a mercurial doctrine persists.

\section{B. Copyright}

Patent law is not alone in viewing the universe as both separate and separable from human artifacts. Although patent law's "products of nature" exclusion is perhaps better developed and more discrete as a doctrine, copyright too contains doctrines that exclude elements of the "natural" world. Copyright is not, in general, concerned with materials and discoveries as is patent law; the iconic examples of copyrightable workstexts, music, sculptures - are quintessentially human products typically not found at large in the world. To some extent, copyright's prohibition on the inclusion of utilitarian or functional items within its ambit excludes many such natural discoveries by shunting them back toward the patent system. Admittedly, this may usher such items out of the intellectual property system altogether; they are denied copyright protection because they fall under patent law, but they may well be denied patent protection because they are considered products of nature.

Nonetheless, even within copyright's proper bailiwick of expressive creations there is the question of how to deal with expression that captures bits of the natural world. ${ }^{71}$ Copyright law explicitly excludes "discoveries" from its subject matter, as well as facts, concepts, and principles from its relevant subject matter. ${ }^{72}$ These exclusions arise not so much from the prohibition against copyright protection for functional subject matter as they do from a corollary to the copyright originality doctrine. Copyright attaches only to original works, meaning that copyrightable subject matter must originate with an author. ${ }^{73}$ Discoveries and facts do not originate with the author, but rather sustain some independent existence apart from human creativity. Much as in the case of unpatentable "laws of nature," copyright assumes that measurements, descriptions of events, and other similar representations of reality are already "out there" waiting to be discerned or found. ${ }^{74}$ Consequently, humans cannot claim credit for their existence.

As we have seen, original copyrightable works are considered to have some type of independent existence, something like Platonic forms, residing as ideal objects in a world of forms. ${ }^{75}$ Matter, as we have seen above, is regarded merely as the medium in which such forms are

71. See Alan L. Durham, Speaking of the World: Fact, Opinion, and the Originality Standard of Copyright, 33 Az. ST. L. J. 791, 803 (2001).

72. 17 U.S.C. $§ 102$ (b) (2006).

73. 17 U.S.C. $\S 102(a)$.

74. See Dan L. Burk, Expression, Selection, Abstraction: Copyright's Golden Braid, 55 SyRACUSE L. REV. 593 (2005).

75. See supra notes 14 and 15 and accompanying text. 
expressed or fixed, and under the mind/body dualism already identified, the tangible is subordinated to the ideal. ${ }^{76}$ But copyright also assumes that descriptions of matter have themselves an independent existence outside of human intervention. These idealized descriptions or measurements sit at the intersection of the idea/expression distinction and the originality doctrine-excluded from copyright in part because they are unoriginal, but primarily because they can be expressed only in a manner that merges fact with expression. ${ }^{77}$

This implies that where one can express a fact or measurement in a variety of ways, there may be originality in the choice of expression-the underlying fact, like an idea, might not be amenable to protection in copyright, but its particular instantiation could be. ${ }^{78}$ Maps, charts, and similar factual representations have long been granted "thin" copyright on this theory, ${ }^{79}$ protecting the expressive choices made in the representation of the facts. ${ }^{80}$ But this possibility has created no end of trouble for courts attempting to determine the potential for copyright protection of certain measurements. Measurements themselves require choices; they require the measurer to decide not only what ought to be measured but how and to what degree of precision. In several cases, courts have attempted to protect such utilitarian choices as "original," leading to the protection of the resulting measurements in copyright despite the prohibition against such protection in precedent and statute. ${ }^{81}$

Cases holding that facts or measurements are protected due to original choices in generating the measurement may result from the court's sense of fairness, an impulse to recognize effort or to foil free riding. ${ }^{82}$ But the cases finding originality in the choices made to generate measurements flag an important anomaly in copyright: facts and measurements cannot occur except as the product of human decisions; they are as constructed and value-laden as works that are typically placed into the copyrightable category of original expression. At a minimum, the line between fact and expression is blurred, and the categories have a good deal of overlap. The failure to recognize this overlap in the law, the attempt to separate these

76. See supra notes 14-17 and accompanying text.

77. See Alan L. Durham, Copyright and Information Theory: Toward an Alternative Model of "Authorship," 2004 BYU L. REV. 69, 99.

78. See id. at 117-18.

79. See Dennis S. Karjala, Copyright in Electronic Maps, 35 JuRIMETRICs J. 395, 413 (1995).

80. See, e.g., Mason v. Montgomery Data, Inc., 967 F.2d 135, 141 (5th Cir. 1992).

81. See, e.g., CCC Info. Serv., Inc. v. Maclean Hunter Mkt. Reports, Inc., 44 F.3d 61, 67 (2d Cir. 1994); Kregos v. Associated Press, 937 F.2d 700, 705 (2d Cir. 1991).

82. See Wendy J. Gordon, On Owning Information: Intellectual Property and the Restitutionary Impulse, 78 VA. L. REV. 149, 156, 167-68, 196 (1992). 
exclusive categories as pristine opposites, the operation of dualistic categories of fact and artifact, signals the presence of an ideological agenda that bears closer scrutiny.

\section{Feminist Insights}

The feminist answer to Mill's concerns quoted above, whether extant in patent or copyright or elsewhere, might be to observe that "nature" constitutes a political category rather than a descriptive one. ${ }^{83}$ Feminist scholarship has devoted considerable attention to the concept of nature and to the ways in which gendered assumptions may infect definitions of nature. ${ }^{84}$ Perhaps the most prominent of such analyses arise out of ecofeminism, where evidence and effects of the patriarchal construction of nature are central to critiquing societal attitudes and actions toward the environment. ${ }^{85}$ Ecofeminist writers have articulated a set of philosophies seeking to relate feminist insights to ecological and environmental thought, applying radical feminism, cultural feminism, and social feminism to develop new forms of environmental practice. Much of this ecofeminist commentary observes that the treatment of the natural world in Western culture parallels the treatment of women and of other subordinated groups, that the same patterns of exploitation and justification are apparent in both forms of abuse. ${ }^{86}$ By dualistically framing either women or nature as an alien "other," domination and subjugation seem justified. Indeed, at some points these conceptual and rhetorical strategies appear to converge, as "Mother Nature" is feminized in both signification and significance. ${ }^{87}$

Ecofeminism has been justifiably criticized for its tendency to adopt a form of essentialism, embracing a philosophy that argues females inherently have a special relationship to the natural world. ${ }^{88}$ Under this view, due to their biological experience of connection in reproduction, women also experience a greater feeling of "connectedness" and empathy towards other living things in general. ${ }^{89}$ This perspective has been criticized as tending towards a new form of dualism that may be equally pernicious as that vilified by ecofeminists themselves. Claiming a special and unique connection between women and nature divides men from

83. See Plumwood, supra note 40 , at 3.

84. Id. at 19.

85. Id. at 4,7 .

86. Id. at 4 .

87. See Carolyn Merchant, The Death of Nature 2-6 (1980).

88. See Plumwood, supra note 40, at 3-4. But see JANET Biehl, Rethinking ECOFEMINIST POLITICS 69-70 (1991).

89. See, e.g., Robin West, Jurisprudence and Gender, 55 U. CHI. L. REV. 1, 2-3 (1988). 
women and assigns to women an emotive role that resembles those used to justify past oppression.

But even though ecofeminism might be faulted for the logic of some of its more dubious incarnations, the core insight remains that conceptualizing humankind as somehow separate from its environment facilitates the exploitation of the natural world. Recognizing that such separation of humans from their surroundings allows human activity to be painted as superior or transcendent allows us to question the rationale and the implications of where the line between the natural and the artificial is drawn. Recognizing the wedge driven between nature and artifice in one setting then allows us to identify in other settings the deployment of a ubiquitous strategy for naturalizing and justifying particular forms of domination.

A similar insight comes from feminist studies of science. Feminist commentators have noted not only the historically sparse participation of women in science, engineering, mathematics, and related fields, but also have interrogated the epistemological structure and hidden assumptions of scientific practice. Among the fundamental perspectives that emerge from such an analysis is a particular scientific view of nature and a corollary relationship of humans to the natural world. Scientific investigation and the factual constructs developed out of scientific investigation gain their authority from their portrayal as rational, objective, and dispassionate observations of the natural world. Feminist commentators dispute whether science is in fact ever so objective, arguing instead that it entails hidden value judgments cloaked by the assertion of objectivity. ${ }^{90}$ In order to assert such objectivity, however, it is necessarily to adopt a standpoint that purposely distances the observer from the world observed. ${ }^{91}$

Some commentators have gone further, arguing that the purported objectivity of science carries its discourse and practice beyond mere separation from the natural world to embrace subjugation of the natural world. ${ }^{92}$ Much of the imagery, many of the metaphors, and many of the literary tropes portraying and justifying the Western scientific enterprise are built around a gendered depiction of nature and the assertion of dominance over that feminized depiction. ${ }^{93}$ Feminist scholars have noted that the proponents of science frequently discuss science in terms that

90. See Ruth Hubbard, Science, Facts, and Feminism, in Women, SCIENCE, AND TECHNOLOGY 153, 157-59 (Mary Wyer ed., 2001).

91. See Bordo, supra note 46, at 8; Evelyn Fox Keller, Reflections on Gender AND SCIENCE 6-8 (1985).

92. See Bordo, supra note 46 , at 50-53.

93. See Harding, supra note 41, at 112-126; CARolyn Merchant, EarthCARe 61 (1996). 
suggest violence or some form of sexual assault. ${ }^{94}$ Scientific apologists back to Francis Bacon describe the scientist as wrestling secrets from nature, tearing the veil from nature, laying nature bare, harnessing, binding, or enslaving nature. ${ }^{95}$ Such imagery seems calculated to push the object of scientific research, a feminized personification of nature, into the background, portraying nature as passive and yielding, as opposed to the foregrounded and active undertaking of scientific investigation.

These insights seem clearly applicable to patent law's product of nature doctrine, as well as to the originality restrictions in copyright. Both doctrines serve to bifurcate human activity from "natural" or "discovered" subject matter, distancing inventive and creative work from the environment in which it necessarily occurs. The former is valorized and celebrated; the latter is obscured and subordinated. Inventions and original works are what count, are what is rewarded; the milieu from which they arise is simply taken as given. Nature is backgrounded, property is foregrounded. Certain types of activities and materials are highlighted, encouraged, and owned; other activities and materials are relegated to common ownership and, by implication, to open exploitation.

Designating "discoveries" as pre-determined, unpatentable, and uncopyrightable determines the type of human endeavor that will dominate innovation and creativity. Designation of a particular resource as a product of nature or unoriginal places it in the "public domain," ironically potentially benefiting those who already hold the greatest stake in privately held intellectual property. As some legal commentators recently have observed, material in the public domain may be freely exploited, but not everyone will necessarily benefit equally from the availability of the resource. $^{96}$ It may be those entities already endowed with the greatest resources that are best positioned to take advantage of such freely available resources. In the parallel case of real property, the designation of some lands as "public" or "common" reinforces the structural dichotomy of public/private control, which may ultimately facilitate further privatization, especially once valuable resources are found on what were previously designated as public or common lands. Designation of certain subject matter in intellectual property as "public" or "common" may have a similar

94. MERChANT, supra, note 87 , at 189-90.

95. See id. at 168-69. Alan Soble has offered an extended defense of Bacon's writings, arguing that Bacon advocated seducing, rather than raping, a feminized personification of nature. See Alan Soble, In Defense of Bacon, in A HouSE BUILT ON SAND 195, 210 (Noretta Koertge ed., 1998). Given that the concern expressed by feminist commentators is one of dominance and exploitation, even granting this reading of Bacon, it is not clear that it is much of an improvement.

96. See generally Anupam Chander \& Madhavi Sunder, The Romance of the Public Domain, 92 CAL. L. REV. 1331 (2004) (lamenting the "tragedy of the commons"). 
effect.

As a practical matter, the standard delineated by the product of nature doctrine pushes patentable subject matter towards high-technology rather than low-technology. The artifact resulting from greater human intervention is more likely to receive the patent reward than the artifact resulting from less intervention. A collection of beneficial bacteria, not occurring together in nature, is still an unpatentable product of nature, but a bacterium resulting from recombinant DNA manipulations is a patentable invention. ${ }^{97}$ The corollary effect would appear to be a bias toward more sophisticated, interventionist, and expensive technologies available to the developed world rather than the simpler technologies available to the developing world. A second corollary is the accumulation of property rights in the developed world in preference to, and possibly at the expense of, accumulation of rights in the developing world. Certainly this has been the accusation leveled by the developing world against the developed world in cases of "biopiracy," where, for example, an efficacious but crude traditional plant extract might fail patentability while high-tech isolation of the active component from the same preparation would qualify for a patent. ${ }^{98}$ The product of nature doctrine, in concert with related patent doctrines, will tend to favor the latter over the former. ${ }^{99}$

Thus, a feminist critique of the product of nature doctrine points to a type of "Matthew effect" in patent law, whereby those who already command significant resources are able to accumulate yet more resources in preference to those who may be in some sense equally or even more innovative but have less to work with. ${ }^{100}$ It would not be difficult to cast this tendency in terms of the colonization and commodification of subordinated peoples, the patriarchal domination of production resources, and ultimately as part of the trend that Donna Haraway has described as "the feminization of poverty." 101 But even without pursuing such intriguing and subversive claims, it is unclear whether such effects of the product of nature doctrine are desirable to patent policy when patent policy is taken on its usual terms; that is, under the utilitarian calculus of promoting progress. A public benefit rationale would not necessarily find

97. Compare Funk Bros. Seed Co. v. Kalo Inoculant Co., 333 U.S. 127, 130-31 (1948), with Diamond v. Chakrabarty, 447 U.S. 303, 309-10 (1980).

98. See, e.g., Robert Paarlberg, The Global Food Fight, 70 ForeIGN AfF. 24, 33-38 (2000).

99. For example, it may be more difficult to accurately describe the plant extract in satisfaction of patent law's written description doctrine. See 35 U.S.C. § 112 (2006).

100. See Robert K. Merton, The Matthew Effect in Science, ScIENCE, Jan. 5, 1968, at 5663 (1968); cf. Matthew 25:29 (King James) ("For unto every one that hath shall be given, and he shall have abundance: but, from him that hath not shall be taken away even that which he hath.").

101. See Haraway, supra note 2, at 167. 
it beneficial to favor the complex over the simple. To pick an example in medical technologies, it is not at all clear that an expensive, highly interventionist new gene therapy to treat heart disease is preferable over a more mundane improved method or device to encourage exercise - the cost to benefit ratio in saving lives and promoting health might well favor the latter simpler development. This could suggest that the doctrine is misguided, or it could suggest that other interests besides the promotion of progress are at issue.

Where copyrightable subject matter is concerned, the exclusion of facts and discoveries from protection as part of the originality doctrine clearly helps define and reinforce the construct of the romantic author. The role of the originality doctrine in sustaining the construction of copyright's romantic author has been explored extensively, including at least one searching analysis from a feminist perspective. ${ }^{102}$ But the effects of demarcating fact from expression is not limited to supporting a suspect notion of authorship, even a suspect notion of authorship that prolongs existing configurations of power. ${ }^{103}$ Much like the product of nature doctrine in patent law, copyright's separation supports the construction of a particular view of reality, which in turn supports established patterns of control and authority in society.

This social function of copyright becomes clearer by adopting Haraway's methodology of examining disputed instances of copyrightable subject matter as "boundary" objects. ${ }^{104}$ Copyright has always had difficulty encompassing documents on the border of fact and expressionnot only modern databases, but more venerable categories of charts, maps, and similar representations of reality - where much of the content would be considered factual, and the expressive choices made by the author are few. ${ }^{105}$ Yet, oddly, the first copyright statute enacted by Congress shortly after the formation of the United States was directed specifically to charts, maps, and similar factual representations bearing only a thin veneer of expression - works of sculpture, music, graphic art, and the other aesthetic staples of copyright were only added to the statute later. ${ }^{106}$

The surprising scope of the initial U.S. statute leaves us to wonder why it addressed subject matter lying very nearly outside the expression, why such factual representations were considered to be matters of the first importance, and why, given their inclusion within copyright at the outset,

102. See Carys Craig, Reconstructing the Author-Self: Some Feminist Lessons for Copyright Law 15 AM. U. J. GENDER SOC. POL'Y \& L. 209.

103. See Burk, supra note 7; Craig, supra note 102.

104. See HARAWAY, supra note 2, at 169.

105. See Burk, supra note 74.

106. See Act of May 21, 1790, ch. 15, 1 Stat. 124 (enacting the first copyright statute). 
such works have been contested ever since. Some indication as to the reasons may be gleaned from critical evaluations of factual constructions outside of copyright. For example, Star and Lampland have investigated the social construction of numerical representation and measurementsprecisely the types of facts that copyright law assumes are independent of human authorship. Such numeric descriptions, they find, are far from "transparent signs" that objectively depict reality, but are rather the products of complex social structures that are legitimized and substantiated and by formal numerical representation. In a similar vein, Harley has examined how maps and other spatial representations are intimately tied to the expansion and maintenance of political power-empires have been keenly interested in the production of charts and maps, in part to establish the legitimacy of their political borders. ${ }^{107}$ Such studies indicate that the depiction of facts is the power to determine what is real, such that control over the construction of facts becomes control over the social perception of reality.

On this view, copyright's dichotomy between fact and expression helps define the boundary between what is real and what is fictional, which in turn defines the boundaries of power and hierarchy. Holding the line between original expression and unoriginal measurements keeps facts immutable, inevitable, and authoritative. Re-categorization of facts as constructed or, in copyright parlance, "original" could threaten to undermine the power structures that rest upon such facts. Allowing charts or maps or other factual depictions to be incorporated too thoroughly within the protection of copyright might dilute their objective force, placing them too close conceptually to expressive works that are clearly the product of imagination. Thus, even though placing factual works outside of copyright lessens the control over those particular works, the overall structure of the law reinforces master discourses that confer dominance in society. And, at the end of the day, courts typically can find enough "originality" in the selection and arrangement of facts to maintain the control of authors over such works as well.

\section{CONCLUSION}

In this essay I have attempted to sketch a critique of two specific doctrinal areas in intellectual property, common to both patent and copyright law, dealing with the related requirements of physical embodiment and human origination. The philosophical contours and implications of these doctrines have gone largely unexplored, although they

107. See J.B. Harley, The New Nature of Maps 67-73 (Paul Laxton ed., 2001); J.B. Harley, Text and Contexts in the Interpretation of Early Maps, in FROM SEA CHARTS TO SATELlite IMAGES 3, 5-8 (David Buisseret ed., 1990). 
are central to the structure of the patent and copyright systems. The dualistic nature of these doctrines lends itself to critical examination using the tools developed in feminist scholarship; feminism has previously addressed the power relationships fostered by such dualisms in other contexts, and critical examination of intellectual property using these tools shows a familiar pattern. To date, intellectual property law has received only scant critical analysis from any discipline, but I am hopeful that the analysis I have undertaken here demonstrates not only that these doctrines entail previously unrecognized assumptions and consequences, but also that feminist methodologies have much to say about the hierarchies, privileges, and power relationships attending the present disposition of intellectual property. 